Багорка М. О., д.е.н., професор Кадирус І. Г., к.е.н., доцент Дніпровський держсавний аграрно-економічний університет м. Дніпро, Україна DOI: https://doi.org/10.30525/978-9934-26-036-0-17

\title{
МАРКЕТИНГОВЕ УПРАВЛІННЯ БІЗНЕС-ПРОЦЕСАМИ ОПТОВИХ ТОРГОВЕЛЬНИХ ПІПРИЕМСТВ
}

На сьогодні оптова торгівля виступає базовою сферою діяльності, яка відіграє провідну роль у товарообігу на вітчизняному внутрішньому та зовнішньому ринках, 3 метою більш повному задоволенню потреб споживачів. 
Ефективну діяльність підприємств оптової торгівлі можна вважати індикатором збалансованого розвитку внутрішнього ринку і каталізатором структурних перетворень. Вкрай важливим $\epsilon$ забезпечення умов для стабільного, динамічного і економічно вигідного розвитку оптових підприємств країни. Активізація діяльності підприємств оптової торгівлі на ринку є запорукою комерційного успіху, але потребує досконалих знань щодо бажань та потреб споживачів, а також вміння швидко та гнучко реагувати на всі їх вимоги.

Механізм оптової торговельної діяльності можна визначити як сукупність принципів, організаційних, фінансових, і економічних форм, методів, способів й інструментів регулювання взаємовідносин учасників оптової торговельної діяльності, 3 метою досягнення найкращих результатів для кожного 3 них. Проявляється такий механізм в комплексі взаємозв'язаних бізнеспроцесів та операцій, що здійснюються у певній послідовності та у своїй сукупності складають даний вид діяльності.

Маркетингова концепція управління оптового торговельного підприємства напряму корелюється 3 бізнес-процесами i пов'язана $з$ операціями по дослідженню купівельного попиту, потреб постачальників і покупців, наданням оптових послуг та розробки раціональних шляхів товароруху.

Мордвінцева Т.В. визнає, що саме маркетинговий підхід являє собою зовнішньо-внутрішню перспективу. Він починається 3 чіткого визначення цільового ринку і концентрації уваги на потребах покупця [1, с. 210].

Ми переконані, що для ефективна робота оптового підприємства залежить від синергічного поєднання маркетингових інструментів з урахуванням особливостей продукції, ринку, поведінки та потреб споживачів, із системою маркетингового управління.

Формування комплексної системи маркетингового управління бізнес-процесами охоплює наступні етапи: 
- дослідження ринку (конкурентного середовища, особливостей попиту і купівельної поведінки споживачів, з'ясування масштабу потенційного і незадоволеного попиту);

- вибір цільового сегмента ринку і формулювання зорієнтованої на його специфіку маркетингової стратегії;

- формулювання мікс-концепції маркетингу - системи заходів щодо ефективного використання результатів маркетингових досліджень, ресурсів і можливостей підприємства 3 метою досягнення найвигіднішого співвідношення витрат і ефектів від них, очікуваних позицій у конкурентній боротьбі, максимального визнання споживачів;

- реалізацію передбачених маркетингових заходів;

- аналіз результатів і коригування подальших дій.

Переважна частина оптових торговельних підприємств поєднує в своїй діяльності бізнес-процеси: закупівлю у постачальників товарів і реалізація товарів операторам роздрібної торгівлі або виробничим споживачам. Маркетингова концепція управління дозволить досягти переваг i забезпечити ефективне управління бізнес процесами (табл. 1).

Бізнес-процеси, що формуються оптовим торговельним підприємством $є$ неоднорідними. Узагальнюючі думки різних науковців, ми дійшли до висновку, що бізнес процеси можна розділити:

- бізнес-процеси орієнтовані на мету оптового підприємства концентрація уваги відбувається на внутрішній структурі, проблемах і вигодах для організації;

- бізнес-процеси орієнтовані на клієнта оптового підприємства - концентрація уваги цінностях, які є важливими, в першу чергу, для клієнтів.

Зазначимо, що маркетингова концепція управління в більшості оптових підприємств поки що не одержала належного поширення внаслідок дії чинників суб'єктивного та об'єктивного характеру. У своїй діяльності оптові підприємства використовують маркетингову систему управління у спрощеному вигляді, тобто виключно для процесу реалізації своїх товарів на ринку. 
Основною перепоною, що постає на шляху переходу до маркетингово-орієнтованої моделі господарювання, є невміння правильно здійснювати маркетингове управління та неспроможність організувати дієвий структурний підрозділ, який би якісно виконував покладені на нього функції маркетингового управління.

Таблиця 1

\section{Характеристика бізнес-процесів \\ оптової торговельної діяльності}

\begin{tabular}{|c|c|}
\hline $\begin{array}{c}\text { Бізнес-процеси } \\
\text { оптової торго- } \\
\text { вельної діяльності }\end{array}$ & Характеристика \\
\hline 1 & 2 \\
\hline $\begin{array}{c}\text { 1. Комерційні } \\
\text { бізнес-процеси за } \\
\text { закупівлі товарів та } \\
\text { надання послуг } \\
\text { постачальникам }\end{array}$ & $\begin{array}{l}\text { об’єднує операції, які орієнтовані на виробничі } \\
\text { підприємства-постачальники. На основі вивчення та } \\
\text { прогнозування купівельного попиту підприємство } \\
\text { оптової торгівлі здійснює пошук потенційних } \\
\text { постачальників та досліджує їх потреби в оптових } \\
\text { торговельних послугах, укладає договори та надає } \\
\text { замовлення на постачання. }\end{array}$ \\
\hline $\begin{array}{c}\text { 2. Комерційні } \\
\text { бізнес-процеси } 3 \\
\text { реалізації товарів та } \\
\text { надання послуг } \\
\text { покупцям }\end{array}$ & $\begin{array}{l}\text { являє собою сукупність операцій, які забезпечують } \\
\text { передумови функціонування роздрібної торговельної } \\
\text { мережі. Акумулюючи дані щодо попиту роздрібної } \\
\text { торгівлі та враховуючи можливості (свої і поста- } \\
\text { чальників) задовольняти цей попит, підприємство } \\
\text { оптової торгівлі визначає раціональні шляхи і форми } \\
\text { товароруху, спрямовуючи частину товарних потоків } \\
\text { безпосередньо в роздрібні підприємства, а інші } \\
\text { концентрує на своїх базах, складах. }\end{array}$ \\
\hline $\begin{array}{c}\text { 3. Логістично- } \\
\text { виробничі операції }\end{array}$ & $\begin{array}{l}\text { включає велику кількість технологічних операцій. Це } \\
\text { обумовлено тим, що в цьому секторі здійснюється } \\
\text { діяльність, яка забезпечує процес надання оптових } \\
\text { торговельних послуг та виконання основних функцій, } \\
\text { притаманних оптовій торговельній діяльності, - } \\
\text { концентрація товарних запасів, доробка, підсорту- } \\
\text { вання і комплектація товарних партій, узгодження } \\
\text { замовлень роздрібних підприємств, завезення товарів } \\
\text { із районів виробництва в райони споживання. } \\
\text { Частина цих товарів накопичується на підприємствах } \\
\text { оптової торгівлі, інша - спрямовується безпосередньо } \\
\text { в роздрібну торгівлю. }\end{array}$ \\
\hline
\end{tabular}


Продовження Таблиці 1

\begin{tabular}{|c|l|}
\hline 1 & \multicolumn{2}{|c|}{2} \\
\hline \multirow{5}{*}{ 4. Фінансові } & забезпечують фінансове супроводження комерційних \\
ба логістично-виробничих процесів і включають: \\
розрахунково-контрольні операції, кредитування \\
постачальників, шляхом здійснення передплати за \\
& товари, та покупців, шляхом надання відстрочки \\
& платежів за поставлені товари. При необхідності \\
& проводиться операція страхування товарних ресурсів, \\
& що стали власністю підприємства оптової торгівлі. \\
\hline
\end{tabular}

Джерело: узагальнено авторами на основі [2, с. 14]

Враховуючи ситуацію, в якій працюють вітчизняні оптові підприємства, маркетингове управління $є$ одним із найбільш важливих резервів підвищення їх економічної ефективності. Об'єднання таких елементів, як товар (послуга), ціна, просування, ринок, споживач та продавець в єдину комплексну систему переводять маркетинг оптового підприємства у статус ведучої управлінської системи в сучасному бізнес-середовищі.

Обгрунтована необхідність пошуку сучасних підходів до управління бізнес-процесами підприємств оптової торгівлі, яка вимагає формування цілісної, науково обгрунтованої системи організації та ефективної системи управління підприємством. Такою системою повинна стати маркетингове управління, яке спрямоване на задовольняння потреб та попиту на ринку, допомагає адаптуватися до змін внутрішнього та зовнішнього середовища, підвищує прибутковість збутової діяльності. Маркетингове управління має поєднати і гармонізувати основні бізнес-процеси оптового підприємства, результатом чого є: для виробника найкращі умови закупівлі; гарантованість та перспективність каналів збуту; розміщення продукції на ринку; умови транспортування; умови складування, мотивація працівників.

Встановлено, що в основі ефективної збутової політики підприємства оптової торгівлі лежить управління бізнеспроцесами закупівельно-збутового підприємства на основі логістично-розподільчої системи. Комплексне управління усіма підсистемами збутової політики, а саме товарною, ціновою 
стимулювання i просування, a також кадровою політикою, допоможе оптовому підприємству підвищити ефективність збутової діяльності.

\section{Література:}

1. Мордвінцева Т.В. Управління маркетинговою діяльністю підприємства в сучасних умовах. Держава та регіони. Серія: Економіка і підприсмниитво. 2006. № 3. C. 209-211.

2. Бондаренко О., Заборська Н. Реінжирінг бізнес-процесів. Науковий вісник ОНЕУ. 2014. №6. С. 11-22.

3. Ільченко Н.Б. Моделювання бізнес-процесів підприємства оптової торгівлі. Науковий вісник Херсонського державного університету. 2015. Вип. 10. Ч. 2. С. 88-91. 